\title{
ТРАДИЦІЙНІ ФАКТОРИ РИЗИКУ ТА ІНТЕРЛЕЙКІН-1О У РОЗВИТКУ ЗАПАЛЕННЯ ТА АТЕРОСКЛЕРОЗУ В ХВОРИХ НА ПСОРІАТИЧНИЙ АРТРИТ
}

\author{
๑Л. В. Хіміон, А. В. Бойко \\ Національна медична академія післядипломної освіти імені П. Л. Шупика, Київ
}

РЕЗЮМЕ. Відомо, що хворі на псоріаз мають підвищений ризик серцево-судинних захворювань (ССЗ) та серцево-судинної смерті, але взаємозв'язок цих подій із впливом традиційних факторів ризику (ФР), запального процесу та розвитку атеросклерозу чітко не встановлено. (ПСА).

Мета - вивчення ролі ФР, запалення, рівня IL10 на розвиток атеросклерозу у хворих на псоріатичний артрит

Матеріал і методи. Дослідження включало 42 пацієнти з ПсА, які не мали атеросклеротичних ССЗ, діабету, хронічної хвороби нирок та інших серйозних захворювань, не приймали статини; порівняльну групу складали 20 пацієнтів із шкірним псоріазом (ПС); у групу контролю увійшли 20 практично здорових осіб, які не мали ознак ревматичних, інфекційних та інших запальних захворювань.

Результати. Встановлено більшу вираженість атеросклеротичного процесу у хворих на ПсА,порівняно 3 пацієнтами із ПС та особами контрольної групи (профілі ФР були однаковими). Найвищі рівні С-реактивного білка, фібриногену, IL10, сечової кислоти, найбільша товщина комплексу інтима-медіа, частота атеросклеротичних бляшок були виявлені у пацієнтів з групи ПсА, що може підтверджувати патогенетичний зв'язок хронічного аутоімунного запального процесу з атерогенезом.

Висновки. У розвитку атеросклеротичного процесу в пацієнтів із ПсА, крім традиційних факторів ризику, важливу роль відіграють імунозапальні фактори (СРБ, IL10) і додаткові фактори ризику (CK).

КЛЮчОВІ СЛОВА: псоріатичний артрит; псоріаз; серцево-судинні захворювання; дисліпідемія; атеросклероз; високочутливий C-реактивний білок; сечова кислота; IL10.

Вступ. Псоріатичний артрит (ПсА) - це запальне захворювання суглобів, ентезисів і хребта, асоційоване з псоріазом [1]. Дані про частоту псоріатичного артриту (ПсА) широко варіюють i складають 0,04-3 \% $[12,17]$. Найчастіше захворювання починається у віці від 20 до 50 років. Захворюваність у чоловіків і жінок однакова $[1,2,17]$. Поширеність ПсА серед пацієнтів з псоріазом (Пс) становить 5,4-34 \% і більше [2, 10, 14]. У свою чергу, популяційна поширеність ПС у переважній більшості досліджень оцінюється в середньому в 0,5$5 \%$, зі значними коливаннями залежно від клімато-географічного регіону $[4,15]$.

Вивченню зв'язку псоріазу та серцево-судинних захворювань приділяється велика увага вітчизняних та зарубіжних учених. Результати клінічних досліджень, опублікованих в останні роки, свідчать про наявність патогенетичного зв'язку між ними, що має багатофакторний характер (Ahlehoff O. et al., 2011). Зокрема, було показано, що у псоріазу та захворювань серцево-судинної системи є загальні фактори ризику. Велика увага приділяється вивченню загальних механізмів розвитку псоріазу та захворювань серцево-судинної системи (Balci D. D. et al., 2009).

Встановлено, що близько 50 \% смертей серед хворих на ПсА обумовлено атеросклероз-залежними серцево-судинними захворюваннями (СС3). За результатами мета-аналізу даних [10], у 55 \% хворих на ПсА був підвищений ризик розвитку
СС3, по відношенню до популяції в цілому, тоді як загальний серцево-судинний ризик у хворих на артрит на 45 \% перевищує середньопопуляційний показник, зокрема, ризик розвитку інфаркту міокарда (IM) був вищий на $68 \%$, захворювань судин головного мозку - на 22 \% і серцевої недостатності-на $31 \%[8,9]$. Більшість авторів вважає, що це пов'язано з наявністю атерогенних дисліпідемій та системного запалення у хворих з ПсА.

Привертає увагу наявність асоціації кардіоваскулярних катастроф зі збільшенням сироваткового рівня багатьох медіаторів, які традиційно використовуються для оцінки активності запального процесу, насамперед С-реактивного білка (СРБ) [7]. Навіть невелике підвищення концентрації СРБ протягом кількох місяців і років, що відображає активність запального процесу, характерного для ПС і ПсА, може бути ФР субклінічного запалення в судинній стінці, яке пов'язане з атеросклеротичним процесом. У цьому плані визначення рівня СРБ за допомогою високочутливого методу (так званий вч-СРБ) дозволяє уточнити ризик розвитку, рецидивування і прогресування судинних ускладнень атеросклерозу [7, 17].

Окрім СРБ, на сучасному етапі вивчається роль сечової кислоти (СК) як нетрадиційного фактора ризику ССЗ та їх ускладнень. Встановлено, що серед хворих на ПС від 19 до 30 \% мають гіперурикемію, рівень якої залежить від площі ураження шкіри. Титов В. Н. і співавт. (2013) показали, що 
Огляди літератури, оригінальні дослідження, погляд на проблему, випадок з практики, короткі повідомлення у осіб з низьким і середнім серцево-судинним ризиком за шкалою SCORE концентрація CK у сироватці крові пов'язана із показниками ліпідного профілю, незалежно від наявності або відсутності метаболічного синдрому, причому взаємозв'язок вмісту СК з ТГ (позитивний) і з ХС ЛПВЩ (негативний) виявлений в усіх досліджуваних групах [8].

У загальній популяції частота асимптомного підвищення рівня СК становить 5-7 \%, за іншими даними - до 12-25\%. Важливими клінічними асоціаціями гіперурикемії $є$ ДЛП, АГ, ожиріння, цД, жовчнокам'яна хвороба та нефролітіаз. Безсимптомну гіперурикемію виявляють у $25 \%$ хворих із АГ, в тому числі у 75 \% хворих з тяжкою АГ (SHEP, 2000) [15]. Враховуючи «традиційні» ФР кардіоваскулярних хвороб, ожиріння та МС, вчені встановили, що рівень СК 6,8-11,1 мг/дл (більше 400 мкмоль/л) в 3,29 раза підвищує вірогідність високого рівня 3ХС та в 1,52 раза - підвищеної кількості СРБ у сироватці крові [17]. Підвищений рівень СК стимулює активацію РААС, посилює дисфункцію ендотелію та провокує АГ. У великому мета-аналізі на основі 18 досліджень, що включав 55607 осіб із середнім періодом спостереження до 6 років, було виявлено, що наявність безсимптомної гіперурикемії збільшує ризик розвитку АГ на $40 \%$ (RR 1,41; $95 \%$ Cl: 1,23-1,58) [16].

У дослідженні ERA підвищена концентрація IL10 була пов'язана з підвищеним ризиком майбутніх серцево-судинних ускладнень у жінок в постменопаузі з встановленим коронарним атеросклерозом [18].

У дослідженні на мишах було виявлено, що дефіцит IL-10 відіграє шкідливу роль при атеросклерозі. Була збільшена рання фаза розвитку ушкодження, а також протеолітична і прокоагулянтна активність. Ці дані показують, що IL10 може знижувати атерогенез і покращувати стабільність бляшок [19].

A. Malarstig, P. Eriksson встановили, що IL10 відображає прозапальний стан у пацієнтів з гострим коронарним синдромом (ГКС), і тому було підтверджено, що він $\epsilon$ таким же ефективним біомаркером для прогнозування ризику майбутніх серцево-судинних подій, як і інші маркери системного запалення [20].

Результати дослідження Ch. Heeschen, St. Dimmeler демонструють, що підвищений рівень сироватки протизапального цитокіну IL10 пов'язаний зі значно кращим результатом пронозу пацієнтів з ГКС. Прогностичне значення рівня сироватки IL10 було незалежним від підвищеного рівня тропоніну, що відображає гострий ризик, спричинений тромботичними ускладненнями під час ГКС. Таким чином, знижений рівень IL10 у сироватці крові $\epsilon$ не лише маркером нестабільності бляшок, що сприяє розвитку ГКС, а й, що ще важливіше, свідчить про поганий прогноз навіть після виникнення ГКС, викликаної нестабільністю бляшок. Крім того, сприятливий вплив підвищених рівнів IL10 у сироватці крові обмежувався пацієнтами з підвищеним рівнем СРБ крові, що свідчить про посилення системної запальної відповіді. Ці дані додатково підтримують концепцію, що баланс між прозапальними та протизапальними цитокінами $\epsilon$ головним визначальним результатом прогнозування ризику фатальних ССЗ [21].

У сучасній літературі $\epsilon$ досить велика кількість досліджень, присвячених пошуку додаткових ФР ССЗ, визначення яких може покращити оцінку та прогноз у пацієнтів із ПсА з різними рівнями серцево-судинного ризику. Проте до цього часу немає чіткої відповіді на багато принципових питань, відповідь на які дала 6 змогу суттєво підвищити ефективність програм профілактики та значно знизити високі рівні смертності та захворюваності на ССЗ у пацієнтів з ПсА.

Мета - визначити особливості атеросклеротичного процесу, серцево-судинниго ризику та впливу IL10 на розвиток атеросклеротичного ураження у хворих на ПсА.

Матеріал і методи дослідження. В дослідження було включено 42 хворих із ПсА, які не мали атеросклеротичних ССЗ, цукрового діабету, хронічної хвороби нирок та інших тяжких захворювань, не приймали статини. У якості групи порівняння було обстежено 20 осіб із ПС, зіставних за віком і статтю, групи контролю - 20 практично здорових осіб, які не мали ознак ревматичних, інфекційних та інших запальних захворювань, були зіставні за статтю і віком з обстеженими хворими. Відібрані хворі на момент включення у дослідження не мали АГ та не приймали гіпотензивних засобів. Усім пацієнтам проводили комплекс клініко-інструментальних та лабораторних обстежень, опитування. Для виявлення ФР ССЗ виконували антропометрію, вимірювання АТ, проводили опитування для виявлення шкідливих звичок (куріння, зловживання алкоголем). Для оцінки наявності депресії та/або тривожних розладів у пацієнтів використовували госпітальну шкали тривоги і депресії (HADS), що призначена для первинного виявлення тривоги та депресії у пацієнтів (скринінгу) в загальномедичній практиці. Обтяжена спадковість визначалась за наявністю атеросклеротичного захворювання або основного ФР (високий АТ, ЦД, ДЛП) у родичів пацієнта першої лінії (мати або батько), які проявились у віці до 55 років у чоловіків та до 65 років - у жінок. Для оцінки ступеня ураження шкіри використовували калькулятор PASI (Psoriasis Area Severity Index). Усім хворим на ПсА визначали індекс активності артриту 
Огляди літератури, оригінальні дослідження, погляд на проблему, випадок з практики, короткі повідомлення (Disease Activity Score - DAS28) за рівнем СРБ, оцінювали середній рівень за два роки. 3 метою визначення групи ризику та осіб, які вживають шкідливу для здоров'я кількість алкоголю, застосовували опитувальник AUDIT (Alcohol Use Disorders Identification Test), розроблений на основі кооперативного проекту ВООЗ (1989р.). Вживання тютюну оцінювали при співбесіді з пацієнтом згідно Наказу МОЗ України від 03.08.2012 № 601 «Про затвердження та впровадження медико-технологічних документів зі стандартизації медичної допомоги при припиненні вживання тютюнових виробів».

Усім хворим та особам групи контролю було проведено комплекс клініко-лабораторних та інструментальних досліджень. Загальне клінічне обстеження включало повне фізикальне обстеження, визначення тяжкості псоріазу, суглобовий огляд. Лабораторне дослідження включало визначення показників ліпідного, пуринового обміну та рівня високочутливого СРБ.

3 метою визначення стану судинної стінки всім включеним у дослідження пацієнтам проводилось дуплексне ультразвукове сканування СА. Відповідно до рекомендацій Європейського товариства кардіологів, сканування СА проводилось у трьох площинах - двох поздовжніх (передній і задній) та одній поперечній. ТКІМ оцінювали у зоні максимального потовщення в орієнтації площи-

ни сканування поздовжній осі судини. Було розраховано середнє значення ТКІМ правої і лівої загальних СА, як середнє 9 вимірювань у 3 положеннях; діагностичним критерієм потовщення ТКІМ вважали показник $\geq 0,9$ мм, наявності атеросклеротичної бляшки - локальне потовщення TKIM >1,5 мм і більше, а6о потовщення більше ніж на 50 \% чи 0,5 мм відносно інших ділянок КІМ.

Математичну обробку отриманих результатів проводили в програмах IBM SPSS 20 та Statistica 10.0 згідно з рекомендацій стандарту GCP до обробки даних. Базу результатів та підготовку даних до математичної обробки проводили в програмі MS Excel 2013.

Результати й обговорення. Середній вік хворих на ПсА становив $(39,62 \pm 5,8)$ років $(15(46,87 \%)$ жінок та 17 (53,13 \%) чоловіків); хворих на ПС (група порівняння) - $(32,3 \pm 5,63)$ років (8 (40 \%) жінок та 12 (60\%) чоловіків) відповідно. Група контролю включала 11 жінок (55 \%) та 9 чоловіків (45 \%), середній вік склав $(32,3 \pm 5,63)$ років. Тривалість ПсА коливалась від 3 до 20 років.

Основні клініко-демографічні характеристики обстежених пацієнтів наведені у таблиці 1.

За результатами початкового обстеження, частота виявлення традиційних та поведінкових факторів ризику ССЗ (куріння, зловживання алкоголем, малорухливий спосіб життя) у групі хво-

Таблиця 1. Клініко-демографічна характеристика пацієнтів, включених у дослідження

\begin{tabular}{|c|c|c|c|}
\hline Показник & $\begin{array}{l}\text { ПсA } \\
\mathrm{n}=42\end{array}$ & $\begin{array}{c}\text { ПС без ПсА, } \\
n=20\end{array}$ & $\begin{array}{c}\text { Контрольна група, } \\
\mathrm{n}=20\end{array}$ \\
\hline Вік, років & $39,62 \pm 4,80$ & $32,30 \pm 5,63$ & $30,75 \pm 2,13$ \\
\hline Жінок, n (\%) & $20(46,62)$ & $8(40)$ & $11(55)$ \\
\hline Чоловіків, n (\%) & $22(52,38)$ & $12(60)$ & $9(45)$ \\
\hline Середня тривалість захворювання & $10,42 \pm 0,34^{*}$ & $4,10 \pm 0,57$ & - \\
\hline DAS 28, бали & & - & - \\
\hline Ремісія <2,6 & $4(8,50)$ & - & - \\
\hline Низький ступінь активності $\geq 2,6<3,2$, n (\%) & $9(21,42)$ & - & - \\
\hline Середній ступінь активності $\geq 3,2<5,1, n$ (\%) & $22(52,38)$ & - & - \\
\hline 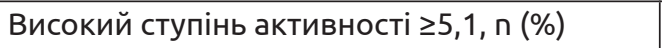 & $7(16,66)$ & - & - \\
\hline PASI, бали & $14,36 \pm 1,12 *$ & $7,20 \pm 1,05$ & - \\
\hline Легке ураження шкіри < 10 балів n (\%) & $9(17,31) *$ & 13(65) & - \\
\hline $\begin{array}{l}\text { Середній ступінь тяжкості ураження шкіри, } \\
\geq 10<20 \text { балів, n (\%) }\end{array}$ & $36(69,23) *$ & $4(20)$ & - \\
\hline Важкий ступінь $\geq 20$ балів, n (\%) & $7(13,46)$ & $3(15)$ & - \\
\hline
\end{tabular}

Примітка. * - різниця між групами достовірна р<0,05. 
Огляди літератури, оригінальні дослідження, погляд на проблему, випадок з практики, короткі повідомлення рих на ПсА достовірно не відрізнялася від групи лю. Частота поєднання факторів ризику ССЗ у хвохворих з ураженням шкіри та осіб групи контро-

Таблиця 2. Фактори ризику ССЗ та стан судинної стінки у обстежених пацієнтів

\begin{tabular}{|c|c|c|c|}
\hline Показник & $\begin{array}{l}\text { ПсА } \\
\mathrm{n}=42\end{array}$ & $\begin{array}{c}\text { ПС без ПсА } \\
n=20\end{array}$ & $\begin{array}{c}\text { Контрольна група } \\
\mathrm{n}=20\end{array}$ \\
\hline $\begin{array}{l}\text { Куріння (будь-коли за останні } 10 \text { років), \% } \\
\text { (кількість осіб) }\end{array}$ & $69,04(29) *$ & $52,63(10) \#$ & $40,00(8)$ \\
\hline Гіподинамія, \% (кількість осіб) & $45,23(19)$ & 47,30 (9) \# & $30,00(6)$ \\
\hline Ожиріння, \% (кількість осіб) & $16,66(7)$ & $15,78(3)$ & $5,00(1)$ \\
\hline Стрес, \% (кількість осіб) & $92,85(39) *$ & 84,20 (16 особи)\# & $50,00(10)$ \\
\hline Обтяжена спадковість по СС3, \% (кількість осіб) & $69,04(29) *$ & $42,10(8)$ & $40,00(8)$ \\
\hline Частота ДлП, \% (кількість осіб) & $83,30(35) *$ & $62,50(20) \#$ & $15,00(3)$ \\
\hline ЗХС, ммоль/л & $5,37 \pm 0,20 *$ & $4,17 \pm 0,44$ & $3,20 \pm 0,10$ \\
\hline ТГ, ммоль/л & $2,45 \pm 0,20 *$ & $1,52 \pm 0,10 \#$ & $1,32 \pm 0,20$ \\
\hline ХС лПВЩ, ммоль/л & $1,19 \pm 0,10$ & $0,76 \pm 0,10 \#$ & $1,32 \pm 0,10$ \\
\hline ХС лПНЩ, ммоль/л & $3,45 \pm 0,80 *$ & $2,43 \pm 0,30 \#$ & $3,12 \pm 0,30$ \\
\hline ХС лПДНЩ, ммоль/л & $0,81 \pm 0,40 * \#$ & $0,5 \pm 0,10 \#$ & $0,62 \pm 0,10$ \\
\hline IA, y.o. & $3,69 \pm 0,90 * \#$ & $2,47 \pm 0,20 \#$ & $2,7 \pm 0,20$ \\
\hline Вч СРБ, (Мг/л) & $8,50 \pm 1,79 * \#$ & $4,45 \pm 0,53 \#$ & $0,77 \pm 0,2$ \\
\hline СК, (мкмоль/л) & $402,85 \pm 15,24 * \#$ & $326,68 \pm 15,59 \#$ & $187,83 \pm 8,20$ \\
\hline Фібриноген & $2,94 \pm 1,02 \#$ & $1,97 \pm 0,77 \#$ & $1,90 \pm 0,20$ \\
\hline SCORE & $3,11 \pm 0,33 * \#$ & $2,43 \pm 0,11 \#$ & $1,71 \pm 0,11$ \\
\hline$<2$ ФР ССЗ \% & $13,05^{*}$ & 15,1 & 14,90 \\
\hline 3-5 ФР ССЗ \% & $69,56^{*}$ & 68,10 & 67,90 \\
\hline$>5$ ФР ССЗ \% & $17,39 *$ & 16,80 & 17,20 \\
\hline Середнє значення ТKIM СА, мМ & $0,93 \pm 0,02 * \#$ & $0,7 \pm 0,01 \#$ & $0,64 \pm 0,02$ \\
\hline Частота ТКІМ >0,9 мм, \% (кількість осіб) & $45,23(19) * \#$ & 25 ( 5 ociб) & $5(1)$ \\
\hline Кількість АБ СА, \% (кількість осіб) & $6,25(2) * \#$ & 0 & 0 \\
\hline Рівень ІЛ-10, пг/мл & $13,33 \pm 1,31 * \#$ & $5,67 \pm 1,01 \#$ & $2,59 \pm 1,02$ \\
\hline
\end{tabular}

Примітки: 1. * - різниця між групами хворих достовірна, p<0,05, 2. \# - різниця з групою контролю достовірна, p<0,05.

За результатами аналізу показників ліпідного обміну відмічалась достовірна різниця середніх рівнів $3 X$ у групі пацієнтів з ПсА (табл. 2), порівняно з групою контролю. У хворих на ПсА середні рівні ЗХ, ТГ, ХС ЛПНЩ, ХС ЛПДНЩ були значно вищими, а рівень ХС ЛПВЩ-достовірно нижчий, порівняно з показниками осіб групи хворих на ПС та групи контролю $(p<0,05)$.
Підвищення рівнів високочутливого СРБ та СК у групі хворих на ПсА відмічено у 78,82 \% (18 осіб) та 21,73\% (5 осіб) відповідно (див. табл. 2).

Як видно з даних, наведених у таблиці 2, частота комбінування поведінкових ФР ССЗ в обстежених групах хворих (ПсА та ПС) не відрізнялась, порівняно із групою контролю. У хворих на ПсА, як і в хворих на ПС, достовірно частіше виявляли дисліпі- 
Огляди літератури, оригінальні дослідження, погляд на проблему, випадок з практики, короткі повідомлення демії-відповідно у 84,30\% пацієнтів з ПсА, у 62,50\%з ПС та у 15,00\% осіб групи контролю $(p<0,05)$.

За результатами обстеження було визначено ризик виникнення фатальних серцево-судинних подій за шкалою SCORE (див. табл. 2), середній показник досліджуваної групи склав $(3,11 \pm 0,33)$.

Збільшення кількості ФГ у сироватці крові $>4$ г/л виявлено у 11 (21,87 \%) пацієнтів, при цьому середній рівень ФГ у сироватці крові склав $(4,20 \pm 0,20)$ г/л. Також було встановлено, що рівень ФГ у сироватці крові достовірно вищий у осіб, які курять, порівняно з пацієнтами, які не курили $(p<0,01)$, та прямо пов'язаний з тривалістю куріння $(r=0,38, p<0,05)$.

Були виявлені достовірні відмінності у вмісті IL10 у групі хворих на ПсА з різним ступенем активності запального процесу, порівняно з групою хворих на ПС та з групою контролю (див. табл. 2).

При порівняльному аналізі показників ліпідного обміну встановлено, що середні рівні 3ХC, ТГ, ХС ЛПНЩ у хворих на ПсА істотно перевищували відповідні показники у хворих на ПС та показники здорових осіб групи контролю. При цьому в результаті кореляційного аналізу виявлено, що найбільший вплив на TKIM CA мали DAS 28, 3XC, XС ЛПНЩ, СРБ, ФГ, PASI IL10 ( $r=0,54,0,68,0,67$, 0,53, 0,52, 0,43, 0,44 відповідно). У групі пацієнтів 3 DAS 28 середнього і високого ступенів активності $(\geq 3,2)$ було виявлено сильний кореляційний зв'язок між величиною ТКІМ СА та рівнем сечової кислоти $(r=0,61)$ та кореляційний зв'язок середньої сили між рівнем IL10 та ХС ЛПНЩ. Рівень ХС ЛПВЩ був пов'язаний сильним зворотним зв'язком 3 СРБ і зворотним зв'язком середньої сили з рівнем сечової кислоти. Між рівнями ФГ, СРБ та СК було виявлено прямий зв'язок середньої сили ( $\ulcorner=0,54$, 0,48 відповідно). Даний аналіз у групі хворих на ПС виявив прямий зв'язок середньої сили між TKIM CA і 3X, XС ЛПНЩ, СРБ ( $r=0,37,0,39,0,38$ відповідно). Результати кореляційного аналізу підтверджують взаємозв'язок запалення з дисліпідемією, яка відіграє значну роль у прогресуванні атеросклеротичного ураження судин і формуван-

ні в подальшому ССЗ. Виявлена кореляція між рівнями IL10 та DAS 28 ( $r=0,38)$, між IL10 та PASI $(r=0,47)$, між IL10 і СРБ $(r=0,48)$ та прямий зв'язок між 3XC та IL17 ( $\ulcorner=0,37)$.

У результаті ультразвукового дослідження сонних артерій виявлено, що хворі на ПсА і ПС мають більшу вираженість атеросклеротичного процесу, порівняно зі здоровими однолітками, що підтверджується більшим середнім значенням ТКІМ у групі хворих на ПсА $(0,93 \pm 0,02)$ p<0,05, порівняно з групою контролю $(0,68 \pm 0,02)$, при цьому ТКІМ $\geq 0,9$ мм виявлено у 45,83 \% хворих на ПсА, що $\epsilon$ доведеним додатковим ФР ССЗ, і у $22,58 \%$ хворих на ПС, що достовірно перевищує показник групи контролю (5 \%). Слід зазначити, що у 6,25 \% хворих на ПсА діагностовано наявність атеросклеротичних бляшок.

Висновки. 1. Поширеність поведінкових ФР ССЗ та їх комбінацій не відрізняється у групах хворих на ПсА, ПС і в групі контролю.

2. Дисліпідемія у хворих на ПсА трапляється частіше, ніж у хворих на ПС $(p<0,05)$ та в осіб групи контролю, що проявляється підвищенням рівня ЗХC, ХС ЛПнЩ і зниженням рівня ХС ЛПВЩ у хворих на ПсА, порівняно з іншими обстеженими.

3. Для хворих на ПсА характерна більша вираженість атеросклеротичного ураження судин, порівняно із хворими на шкірний псоріаз і здоровими однолітками, що підтверджується більшою частотою виявлення АБ і ТКІМ $\geq 0,9$ мм у сонних артеріях та більшим середнім значенням TKIM, порівняно із групами порівняння та контролю.

4. У хворих на ПсА відзначається достовірне підвищення кількості IL10 в сироватці крові, порівняно зі здоровими особами та хворими на шкірний псоріаз, що може свідчити про зростання синтезу цього протизапального цитокіну у відповідь на хронічний імунозапальний процес, характерний для ПсА.

5. У розвитку атеросклеротичного процесу в пацієнтів із ПсА, крім традиційних факторів ризику, важливу роль відіграють імунозапальні фактори (СРБ, IL10) і додаткові фактори ризику (CK).

\section{ЛІТЕРАТУРА}

1. Бадокин В. В. Терапевтическая активность и безопасность артрофоона при псориатическом артрите / В. В. Бадокин, Ю. В. Бадокин. Л. Корсакова // Consilium Medicum [Электронный ресурс]. - 2006. - № 8. - Режим доступа: http://con-med.ru/magazines/consilium_medicum/ 212569/212305 (дата обращения: 27.03.2014).

2. Cytokine profiles during infliximab monotherapy in psoriatic arthritis / A. Mastroianni, E. Minutilli, A. Mussi [et al.] // British Journal of Dermatology. - 2005. - Vol. 153, No. 3. - P. 531-536.

3. Gottlieb A. B. Psoriasis comorbidities / A. B. Gottlieb, C. Chao, F. Dann // Journal of Dermatological Treatment. 2008. - Vol. 19, No. 1. - P. 5-21.

4. Milosavljevic J. Ultrasound and Power Doppler Evaluation of the Hand and Wrist in Patients with Psoriatic Arthritis / J. Milosavljevic, U. Lindqvist, A. Elvin // Acta Radiologica. - 2005. - Vol. 46, No. 4. - P. 374-385.

5. Guidelines of care for the management of psoriasis and psoriatic arthritis: Section 2. Psoriatic arthritis: overview and guidelines of care for treatment with an emphasis on 
Огляди літератури, оригінальні дослідження, погляд на проблему, випадок з практики, короткі повідомлення the biologics / A. Gottlieb, N. J. Korman, K. B. Gordon [et al.] // Journal of the American Academy of Dermatology. 2008. - Vol. 58, No. 5. - P. 851-864.

6. Ellis C. N. Effects of alefacept on health-related quality of life in patients with psoriasis results from a randomized, placebo-controlled phase II trial / C. N. Ellis, M. M. Mordin, E. Y. Adler // American Journal of Clinical Dermatology. - 2003. - Vol. 4, No. 2. - P. 131-139.

7. Stefano I. Echographic test and cyclosporin therapy in psoriatic arthritis / I. Stefano, R. Eugenio, R. Antonio // Journal of the European Academy of Dermatology and Venereology. - 2000. - Vol. 14, No. 3. - P. 232-233.

8. Кочергин Н. Г. Итоги работы Первой всемирной конференции по псориазу и псориатическому артриту / Н. Г. Кочергин, С. Н. Кочергин, Л. М. Смирнова // Русский медицинский журнал. - 2006. - Режим доступа: http://www.rmj.ru/articles_4306.htm (дата обращения: 03.04.2014).

9. Psoriasis and diabetes: a population-based crosssectional study / A. D. Cohen, J. Dreiher, Y. Shapiro [et al.] // Journal of the European Academy of Dermatology and Venereology. - 2008. - Vol. 22, No. 5. - P. 585-589.

10. Взаимосвязь мочевой кислоты с показателемя липидного обмена у лиц с низким и средним риском по шкале SCORE / В. Н. Титов, С. А. Бойцов, С. Ф. Уразалина [и др.] // Атеросклероз и дислипидемия. - 2013. - № 2. C. 31-39.

11. Chandran, V. Sensitivity and specificity of the caspar criteria for psoriatic arthritis in a family medicine clinic setting / V. Chandran, C. T. Schentag, D. D. Gladman // The Journal of Rheumatology. - 2008. - Vol. 35, No. 10. P. 2069-2070.

12. Митченко О. И. Дислипидемии: дагностика. профилактика и лечение : метод. рек. асоциаций кардиологов Украины / О. И. Митченко, М.И.Лутай. - К. : Морион, 2011.

13. Вплив імунного статусу та ліпідних факторів на прогресування субклінічного атеросклерозу та розвиток серцево-судинних захворювань у пацієнтів із ревматоїдним артритом // В. М. Коваленко, Л. В. Хіміон, Г. І. Лисенко, О. О. Гарміш // Укр. ревматол. Журн. 2011. - № 44 (2). - С. 23-31.

\section{REFERENCES}

1. Badokin, V.V., Badokin, Yu.V., \& Korsakova, L. (2006) Terapevticheskaya aktivnost i bezopasnost artrofoona pri psoriaticheskom artrite [Therapeutic activity and safety of an arthropoon in psoriatic arthritis]. Consilium Medicum. 8. Retrieved from: http://con-med.ru/magazines/consilium_ medicum/ 212569/212305 [in Russian].

2. Mastroianni, A., Minutilli, E., Mussi, A., Bordignon, V., Trento, E., D'Agosto, G., ..., \& Berardesca, E. (2005). Сytokine profiles during infliximab monotherapy in psoriatic arthritis. British Journal of Dermatology, 153 (3), 531-536.

3. Gottlieb, A.B., Chao, C., \& Dann, F. (2008). Psoriasis comorbidities. Journal of Dermatological Treatment, 19 (1), 5-21.

4. Milosavljevic, J., Lindqvist, U., \& Elvin, A. (2005). Uttrasound and Power Doppler Evaluation of the Hand and Wrist in Patients with Psoriatic Arthritis. Acta Radiologica, 46 (4), 374-385.

5. Gottlieb, A., Korman, N.J., Gordon, K.B., Feldman, S.R., Lebwohl, M., Koo, J.Y., ..., \& Menter, A. (2008). Guidelines of care for the management of psoriasis and psoriatic arthritis: Section 2. Psoriatic arthritis: overview and guidelines of care for treatment with an emphasis on the biologics. Journal of the American Academy of Dermatology, 58 (5), 851-864.

6. Ellis, C.N., Mordin, M.M., \& Adler, E.Y. (2003). Effects of alefacept on health-related quality of life 
Огляди літератури, оригінальні дослідження, погляд на in patients with psoriasis results from a randomized, placebo-controlled phase II trial. American Journal of Clinical Dermatology, 4 (2), 131-139.

7. Stefano, I., Eugenio, R., \& Antonio, R. (2000). Echographic test and cyclosporin therapy in psoriatic arthritis. Journal of the European Academy of Dermatology and Venereology, 14 (3), 232-233.

8. Kochergin, N.G., Kochergin, S.N., \& Smirnova, L.M. (2006). Itogi raboty Pervoy vsemirnoy konferentsii po psoriazu i psoriaticheskomu artritu meditsinskiy zhurnal [Results of the First World Conference on Psoriasis and Psoriatic Arthritis]. Retrieved from: http://www.rmj.ru/ articles_4306.htm [in Russian].

9. Cohen, A.D., Dreiher, J., Shapiro, Y., Vidavsky, L., Vardy, D.A., Davidovici, B., Meyerovitch, J. (2008). Psoriasis and diabetes: a population-based cross-sectional study. Journal of the European Academy of Dermatology and Venereology, 22 (5), 585-589.

10. Titov, V.N., Boytsov, S.A., Urazalina, S.Zh., Sergiyenko, I.V., Andreyenko, Ye.Yu., Kukharchuk, V.V., \& Karpov, Yu.A. (2013). Vzaimosvyaz mochevoy kisloty s pokazatelyamy lipidnogo obmena u lits $s$ nizkim i srednim riskom po shkale SCORE. Ateroskleroz i dislipidemiya Atherosclerosis and Dyslipidemia, 2, 31-39 [in Russian].

11. Chandran, V., Schentag, C.T., \& Gladman, D.D. (2008). Sensitivity and specificity of the caspar criteria for psoriatic arthritis in a family medicine clinic setting. The Journal of Rheumatology, 35 (10), 2069-2070.

12. Mitchenko, O.I., \& Lutay, M.I. (2011). Dislipidemiya: diagnostika, profilaktika i lecheniye: metod. rek. asotsiatsiy kardiologov Ukrainy [Dyslipidemia: diagnosis, prevention and treatment: methodological recommendations of Associations of Cardiologists of Ukraine]. Kyiv: Morion, 2011.

13. Kovalenko, V.M., Khimion, L.V., Lysenko, H.I., \& Harmish, O.O. (2011). Vplyv imunnoho statusu ta lipidnykh faktoriv na prohresuvannia subklinichnoho aterosklerozu ta rozvytok sertsevo-sudynnykh zakhvoriuvan u patsiientiv iz revmatoidnym artrytom [Influence of immune status and lipid factors on the progression of subclinical atherosclerosis and the development of cardiovascular disease in patients with rheumatoid arthritis]. Ukr. revmatol. Zhurn. - The Ukrainian Journal of Rheumatology, 44 (2), 23-31 [in Ukrainian].

14. Gonzalez-Juanatey, C., Llorca, J., Amigo-Diaz, E., Dierssen, T., Martin, J., \& Gonzalez-Gay, M.A. (2007). High prevalence of subclinical atherosclerosis in psoriatic arthritis patients without clinically evident cardiovascular облему, випадок з практики, короткі повідомлення disease or classic atherosclerosis risk factors. Arthritis Rheum., 57 (6), 1074-1080.

15. Franse, L.V., Pahor, M., Di Bari, M., Shorr, R.I., Wan, J.Y., Somes, G.W., \& Applegate, W.B. (2000). Serum uric acid, diuretic treatment and risk of cardiovascular events in the Systolic Hypertension in the Elderly Program (SHEP). J. Hypertens., 18, 1149-1154.

16. Grayson, P.C., Kim, S.Y., LaValley, M., \& Choi, H. (2011). Hyperuricemia and incident hypertension: a systematic review and meta-analysis. Arthritis Care Res. (Hoboken), 63 (1), 102-110.

17. Keenan, T., Blaha, M.J., Nasir, K., Silverman, M.G., Tota-Maharaj, R., Carvalho, J.A., Conceição, R.D., ..., \& Santos, R.D. (2012). Relation of uric acid to serum levels of high-sensitivity C-reactive protein, triglycerides, and highdensity lipoprotein cholesterol and to hepatic steatosis. Am. J. Cardiol., 110 (12), 1787-1792.

18. Lakoski, S.G., Yongmei Liu, M.S., Bridget Brosnihan, K. \& Herrington, D.M. (2008). Interleukin-10 concentration and coronary heart disease (CHD) event risk in the estrogen replacement and atherosclerosis (ERA) study. Atherosclerosis, 197 (1), 443-447.

19. Caligiuri, G., Rudling, M., Ollivier, V., Jacob, M.P., Michel, J.B., Hansson, G.K., Nicoletti, A., et al. (2003). Interleukin-10 deficiency increases atherosclerosis, thrombosis, and low-density lipoproteins in apolipoprotein $\mathrm{E}$ knockout mice. Molecular Medicine, 9, 10-17.

20. Mälarstig, A., Eriksson, P., Hamsten, A., Lindahl, B., Wallentin, L., \& Siegbahn, A. (2008). Raised interleukin-10 is an indicator of poor outcome and enhanced systemic inflammation in patients with acute coronary syndrome. Heart, 94, 724-729.

21. Heeschen, C., Dimmeler, S., Hamm, C.W., Fichtlscherer, S., Boersma, E., Simoons, M.L., Zeiher A.M., et al. (2003). Serum level of the antiinflammatory cytokine interleukin-10 is an important prognostic determinant in patients with acute coronary syndromes. Heart, 107, 21092114.

22. Mease, P., \& Goffe, B.S. (2005). Diagnosis and treatment of psoriatic arthritis. J. Am. Acad. Dermatol., 52 (9), 1-19.

23. Mastroianni, A., Minutilli, E., Mussi, A., Bordignon, V., Trento, E., D'Agosto, G., Cordiali-Fei, P., \& Berardesca, E. (2005). Cytokine profiles during infliximab monotherapy in psoriatic arthritis. British Journal of Dermatology, 153 (16), 531-536.

\title{
ТРАДИЦИОННЫЕ ФАКТОРЫ РИСКА И ИНТЕРЛЕЙКИН-10 В РАЗВИТИИ ВОСПАЛЕНИЯ И АТЕРОСКЛЕРОЗА У БОЛЬНЫХ ПСОРИАТИЧЕСКИМ АРТРИТОМ
}

ФЛ. В. Химион, А. В. Бойко

\author{
Национальная медицинская академия последипломного образования имени П. Л. Шупика, Киев
}

РЕЗЮМЕ. Известно, что больные псориазом имеют повышенный риск сердечно-сосудистых заболеваний (ССЗ) и сердечно-сосудистой смерти, но взаимосвязь этих событий с влиянием традиционных факторов риска (ФР), воспалительного процесса и развитием атеросклероза четко не установлена.

Цель - изучение влияния ФР, воспаления, уровня IL10 на развитие атеросклероза у больных псориатическим артритом (ПСА). 
Огляди літератури, оригінальні дослідження, погляд на проблему, випадок з практики, короткі повідомлення

Материал и методы. Исследование включало 42 пациента с ПсА, которые не имели атеросклеротических СС3, диабета, хронической болезни почек и других серьезных заболеваний, не принимали статины; сравнительную группу составляли 20 пациентов с кожным псориазом (ПС), в группу контроля вошли 20 практически здоровых лиц, не имевших признаков ревматических, инфекционных и других воспалительных заболеваний.

Результаты. Установлено большую выраженность атеросклеротического процесса у больных ПСА, по сравнению с пациентами с ПС и лицами контрольной группы (профили ФГ были одинаковыми). Наивысшие уровни C-реактивного белка, фибриногена, IL10, мочевой кислоты, наибольшая толщина комплекса интима-медиа, частота атеросклеротических бляшек были обнаружены у пациентов из группы ПСА, что может подтверждать патогенетическая связь хронического аутоиммунного воспалительного процесса с атерогенезом.

Выводы. В развитии атеросклеротического процесса у пациентов с ПСА, помимо традиционных факторов риска, важную роль играют иммуновоспалительные факторы (СРБ, IL10) и дополнительные факторы риска (СК).

КЛЮчЕВЫЕ СЛОВА: псориатический артрит; псориаз, сердечно-сосудистые заболевания; дислипидемия; атеросклероз; высокочувствительный C-реактивный белок; мочевая кислота; IL10.

\title{
TRADITIONAL RISK FACTORS AND IL10 IN INFLAMMATION AND ATHEROSCLEROSIS DEVELOPMENT IN PATIENTS WITH PSORIATIC ARTHRITIS
}

\author{
○L. V. Khimion, A. V. Boiko \\ P. Shupyk National Medical Academy of Postgraduate Education, Kyiv
}

SUMMARY. It is known that patients with psoriasis have increased risk of cardiovascular diseases (CVD) and cardiovascular death but the relationship of those events with influence of traditional risk factors (RF), inflammatory process and atherosclerosis development is not clear.

The aim - to study the role of RF, inflammation, level of IL10 in development of atherosclerosis in patients with psoriatic arthritis (PsA).

Material and Methods. The study included 42 patients with PsA who did not have atherosclerotic CVD, diabetes, chronic kidney disease and other serious diseases, did not take statins; the comparing group consisted of 20 patients with skin psoriasis (PS); and 20 practically healthy individuals who had no signs of rheumatic, infectious and other inflammatory diseases.

Results. It was found that in patients with PsA, the severity of the atherosclerotic process was more prominent compared to patients with PS and control group (the RF profiles were the same). The highest levels of C-reactive protein, fibrinogen, IL10, uric acid, intima-media complex thickness (IMT), atherosclerotic plaques frequency were found in patients in the PsA group, which may indicate a pathogenetic association of additional RF with the development of a more common atherosclerotic process.

Conclusions. In the development of atherosclerotic process in patients with PsA, in addition to the traditional risk factors, an important role is played by immune-inflammatory factors (CRP, IL10) and additional risk factors (CK).

KEY WORDS: psoriatic arthritis; psoriasis; cardiovascular diseases; dyslipidemia; atherosclerosis; C-reactive protein; uric acid, IL10.

Отримано 24.11.2019 